\title{
The Russian Revolution, Effects on the Establishment of the Turkey Republic
}

\author{
Sabir Mirzazada* \\ Sapienza University of Rome, Master degree, Political Science, Italy \\ *Corresponding Author: Sabir Mirzazada, Sapienza University of Rome, Master degree, Political \\ Science, Italy
}

\begin{abstract}
The defeats on the fronts, economic hardships, and bad management created great anger among the general public and paved the way for a social shock by First World War. The main demand of Russian People was terminating the War. The strikes, became intensified day by day, evolved into the wave of revolution and at last, the Romanov Dynasty ended with the revolution on February 27, 1917. The point is that the effects of the revolution would not end with the borders of Russia. That is a fact, World Order could not remain the same after the Revolution. The events managed to affect the whole world in different ways in the form of waves, but it is possible to see various forms of these effects in history. But some nations and countries had a direct and immediate share from this wave, and the Ottoman Empire was one of the most obvious examples among them. These were two societies influenced by each other over the centuries, but this time there were traces of the Russian Revolution, the destiny of the Ottoman Empire.
\end{abstract}

Keywords: The Russian Revoultion, First World War, Ottomans, Turkey Republic , Bolsheviks

\section{INTRODUCTION}

The issue that we will deal with as a subject will be dealt with mainly with two empire-owned nations. Turks and Russians are two nations that have fought against each other throughout history. The main reason for this was that Tsarist Russia was a land state which was not connected with the seas in the first periods. The most important way for Russia to reach the warm seas was through the territory of the Ottomans. Naturally, these maneuvers of the Russians led to the beginning of the competition process between the two states. For this reason, the geopolitical positions of the Ottoman Empire and Russia caused the relations between the two nations to deteriorate and to constantly fight each other also it caused their influence each other. The goal of the Russians, especially starting from the Great Tsar Petro, to have the Straits of Istanbul has become a purpose for the Russian state until the First World War. At the beginning of the 20th century, although both the Ottoman Empire and Russia had many common points, their relations could not improve positively. In the century in question, as it is today, it is making efforts to integrate with this world gradually against the European world, but could not be integrated with Europe in any way, but also did not trust Europe and There were two Eurasian empires that were not adopted by Europeans either in practically. By the time of the First World War, these two underdeveloped empires were on the opposite fronts, one of the most important factors was that the Ottomans kept alongside the Germans to protect the Straits. Likewise, the Russians relied on the support of the British to get a share in the control of the Straits. As we will discuss in our study, things did not go well for Russia in the Canakkale wars and the process leading to the Revolution was accelerated. The first major impact of the revolution was manifested in the Brest Litovsk treaty, and Results of the events that Ottomans contributed to their acceleration by the victory of Canakkale, that would be returned to Turks as a counter effect

\section{The Main TRigger OF THE Process: World WAR I}

The last great war had happened in the 1877-78 year between the Ottoman and Russia before the First World War, the Ottoman lost again and had to sign a treaty under heavy conditions. With this war, the three provinces lost by the Ottomans in Anatolia, Kars, Batumi, and Ardahan were only recovered with the Brest-Litovsk treaty by Ottomans. Turkish-Russian relations were generally in conflict because of the desire of the Russians to land in the warm seas. Due to Russia's desire to descend to the south, the Russian pressure on Eastern Anatolia, the Balkans, and the Straits has always continued and 
this pressure has made itself felt more on the Straits. The Straits problem had always been of special importance since the time of the First World War when the imperialist powers were struggling to obtain colonies and to share Ottoman lands. Indeed, the issue of the straits in the Ottoman-Russian relations had always been the determining factor between the two states. Before War, these empires were on the opposite fronts, one of the most important factors was that the Ottomans kept alongside the Germans to protect the straits, and the Russians also relied on the support of the British for the Straits. But the course of the war did not progress as the Russians had wanted. Although the Russian empire had a large army ready for war, it lacked the economic power to feed it. Besides, the increasing revolutionary activities during the war made it impossible for the Russian state to continue a long-running war. The First World War has an important place in addressing our topic because defeats in the war were also important in the acceleration of the revolutionary process and the fall of the tsarist regime. Although the Russian army won victories over the weak Ottoman army, it was defeated by the Germans who had a modern army for that period. Successive news of military defeat from the front shook the Tsar's authority in Petersburg. On the other hand, despite the defeats on the eastern Anatolian front, the Ottoman victory by German support, over the British-French forces in the battle of Canakkale had caused problems for Russians. The Russian government was deprived of aids of its allies by this situation, which would come through The Straits of Istanbul. It is possible to see this event as an indirect contribution of the Ottomans to the Russian revolution. Summing up the situation of the Ottomans, even though they achieved local victories in Iraq and the Straits, the Ottoman army in Palestine and Eastern Anatolia was defeated. Although the Ottomans did not face serious internal political opposition like Russia, there were serious problems in the army and state administration. Thus, in 1917, the news from Russia was especially welcomed in the Ottoman society and press. Romanovs, whom they saw as responsible for centuries-long rivalry with Ottomans was overthrown by Revolution.

\section{WHICH REVOLUTION?}

Especially in the absence of the February 27 Revolution, the opinion that the coup of the palace would be in March or April had spread. On the days when the events took place, the President of the State Duma Mikhail Rodziyanko had telegraphed Tsar Nikola and the army commanders; He stated that the popular movement that emerged in Petrograd spontaneously emerged and reached dangerous dimensions. It was stated that the defense industry started to collapse, the number of unemployed people lost their jobs, and the panic among the people and the public did not have confidence in management. He telegraphed on II Nikola again and told the Emperor that he had to give an order to form a new government, that Tsar should declare new decree opening the State Duma again, otherwise he would have said that this negative ambiance would spread to the army and cause Germany to triumph and end Russian empire. Thus, Petrograd workers increased day by day to Nevski Boulevard and the general strike turned into an uprising. The government was overthrown on February 27. Along with the difficulties brought by the war, the distrust of the regime in the society and the problem of communication between the governing levels of the state accelerated the road to the February revolution. Besides all this, Russia was entering a new era. The February Revolution, which ultimately led to expectations in the Russian community, tried to establish a new political system, the Russian Republic until the Bolsheviks came to power. So the President of the Provisional Government stated that the Russian Revolution that emerged during the First World War was miraculous in his depiction of the February Revolution in his speech. It was emphasized that the miracle that came with change was the source of it and that the freedom gained by the Russian Revolution was a universal element, thus forming the basis of world democracy and guiding the principles of freedom, brotherhood, and equality Although the words of the President were popular and promising for that period, the revolution did not achieve many of the goals set in the ongoing process, that although it broke an unfair order, the situation allocated for it was controversial, and although social equality was partially achieved, the same steps could not be taken for human rights and political freedoms. These were sides of the situation for the Russian community in that period but for Ottomans, the subject of foreign politics, that is, the attitude of the Provisional government in the war, did not meet the expectations in Istanbul. Firstly Milyukov, then Alexander Kerensky had repeated their minds about continue of war. For example, Alexander Kerensky had an interview with Petrograd reporter of London Daily Newspaper, stated that they wanted to bring Istanbul to international status and that Armenia would have independence, Besides, the Armenian state mentioned by Kerensky was envisaged to consist of provinces within the Ottoman borders for that 
period,(Although modern Armenia was founded inside of Russian Empire borders in Southern Caucasus after First World War). This statement of the interim government official meant the continuation of the war because the status of Istanbul and the Armenian issue were among the red lines of the Ottoman Empire at that time. As can be seen, even though there were administrative and political changes with the February revolution, there was no major change in foreign policy, and even the Provisional Government became more dependent on the British government for support and aids. Although all other political powers in Russia for this period were almost in agreement with the continuation of the War, the Bolsheviks insisted on peace. Because this was the desire of masses, on the other hand, the Russian state had no power to continue the war on its own. For that period, the charming character of the right-wing forces, General Kornilov even imposed the execution of the Bolsheviks against their propaganda in the army. But the actors who were against the Bolsheviks sought to deal with the accounts within themselves, that Kornilov's military coup attempt and subsequent help from the Bolsheviks revealed how weak the government was. The Provisional government could not take a step towards the economy within this political structure, so the economy was deteriorating. Unemployment, food shortages and inflation rates have become serious issues. In addition, Kerensky had no reputation such as early periods. The Bolsheviks captured the majority in the Petrograd Soviet on August 31, and the Moscow Soviet on September 5. Seeing that the government was losing power and had no motivational legitimate in society, Lenin and his surroundings took action to seize the opportunity. At the committee meeting of Bolsheviks held in October, a decision was taken to overthrow the Provisional Government with an armed insurrection. The first step towards this initiative was taken with the establishment of the military-revolution committee. Trotsky, the leader of this committee, continued his work keeping all activities confidential. The armed uprising to be held was planned before the Second Congress of All-Russian Soviets. On the 25th of October, the Bolshevik Revolution began with the cannon shots from the Avrora warship, and Bolsheviks had won the end of this famous historical story. But the part directly related to our subject occurred right after the October Revolution. After the peace declaration written by Lenin on October 26, 1917, was accepted, it resonated all over the world. According to the declaration, the Workers and Peasants' government, which came to power as a result of the revolution, offered to start negotiations immediately to make a fair and democratic peace among all sides. This peace would be accomplished without annexation and compensation. This decree has resulted in the belief of Lenin and Bolsheviks, and the war had to be ended as soon as possible for the Soviet Government to survive. The Bolsheviks adopted this declaration to lay the foundations of the Russian revolution. Lenin's view of peace was not new, because he had described the First World War as a "predatory imperialist war" in the "April theses" published after the February revolution. Peacefully, the country would be breathed and time would be saved. All conditions for that period were supposed to end the war for Russia, as well as peace needed for the ideological spread of the Bolsheviks. It is a fact that, besides the difficult situation of the Russian state and its people, the revolutionary Bolsheviks needed peace to establish their regimes throughout the country, But this peace was not vital for only Bolsheviks. As of the same period, the Ottoman government needed such peace, both to take back the eastern Anatolian lands from Russians, and at least stopping military operations on one front would relieve the army for other fronts. The talks of the Brest-Litovsk peace took place in such an environment, and when we look at the parliamentary speeches and the news in the press, we can see that the Ottoman public had welcomed the event. For example, "Sabah" newspaper on November 30, 1917, "When is General Peace?" In the editorial of İsmail Mushtak: The author praised the Russian Revolution's "peace without compensation and compensation" formula. "This formula is the product of a mentality that embraces the future, According to İsmail Mushtak Bey, also the rejection and condemnation of the past politics by the revolutionaries was a strong reason for the Bolsheviks to be trusted not only with their current peace proposals but also their policies after peace. Also in the parliamentary negotiations at that time, Deputies were praising the Bolsheviks who offered peace and On the other hand, they stated that the revolution would end the century-long rivalry between the Russians and the Turks. Later, consecutive discussions on this issue took place in the there. Emin Bey, the Mosul deputy, made an interesting speech, he pleased the Bolsheviks for overthrowing the Russian Tsarist regime, Emin bey once again said that they (Romanovs) were Ottoman and Turkish enemies. In fact, the view of the Mosul deputy was a general belief in Muslim societies at the time, because the centuries-old wars of the Russian empire with the Ottomans had created a "demon" image for the Russian regime in the Ottoman-Muslim society. But it is worth emphasizing once again that one of the most important reasons why the Ottoman society was so happy that the war ended was that 
the situation of the army and the state structure was bad. In other words, the Bolsheviks were also saving the Ottoman empire from a heavy burden. The Brest-Litovsk treaty was the first powerful influence and result of the Russian revolution for the Ottomans. On the other hand, considering the starting process of the Brest-Litovsk peace, it is possible to find the answer to our "which revolution" question. The fact is, the process for this peace treaty started only with the October revolution when the Bolsheviks took control. To summarize, the first major impact of these movements in Russia on the Ottomans was touched by the October Revolution, but the October Revolution occurred at the end of the process that started with the February Revolution. Returning to the Brest Litovsk treaty, even though the Ottomans were relieved of a military burden on the eastern front, they could not convert this interim period into an opportunity for a general peace. Namely, after the defeats in Damascus and Palestine in the next course of the war, the Ottoman government started negotiations to surrender. After the Mudros armistice was signed, the official war between the British Empire and the Ottoman Empire was over, but the English forces occupied Istanbul using their rights as per article 7 of the treaty.

Under these severe conditions, Turkish officers and former İttihadists (İttihad and Terakki party) started a struggle in Anatolia, far from Istanbul, as a solution.

\section{NATIONAL STRUGGLE FOR INDEPENDENCE AND BOLSHEVIKS}

The world war was lost, the British armies were in the capital, the Sultan himself and his government tended to deal with the British and even became dependent on them. Besides, when the Greeks had invaded İzmir, the situation became more difficult. Old allies in World War I were also in a difficult situation and were dealing with their internal problems. In this period, another force against the British could help them, and the dialogue of the National Struggle with the Bolsheviks had begun under such circumstances. When the Mudros armistice Treaty was signed, some of the members of the Ittihadists went abroad, and some moved from Istanbul to Anatolia for redemption from courts. The first relations with Soviet Russia, on the other hand, started in that period, and the fact that the İttihadists were abroad enabled the Russians to establish their first connections with the Turks through them. The former military leader of the Ottoman empire, who once fought on the opposite side of the Russian Empire during War, Enver Pasha was invited to Moscow this time for an alliance. As for the first contacts of the Bolsheviks in the Turkish territory, the first contacts begin with Mustafa Suphi and his friends reaching Crimea on January 22, 1919. Ittihadist Turkish officers who remained here after the Turkish army withdrew from the Caucasus also played an important role at the beginning of the Turkish-Soviet relations. After the Mudros Armistice, Turkish officers and the members of the "Teşkilat-1 Mahsusa"(Extension of CUP), who stayed in Azerbaijan were working with the Karakol Society. The main reason why the Bolsheviks chose the Ittihadists to establish a relationship was that it was the best-organized organization at that time. Also, the Bolsheviks had good relations with the Ittihadists as a requirement of their policies. Because the Panturanist and Panislamist leaders would prevent the Turks living in Russian lands from opposing the Bolsheviks, preventing Britain from putting pressure on Russia by making revolts in the Muslim colonies of Britain, and in the future, these leaders such as Enver Pasha, would use it as an element of balance against Mustafa Kemal. But at the end of the process, these alliance attempts did not succeed and Enver pasha had gone to Central Asia and took part there in the local revolt against the Bolsheviks and died there. However, it did not end the relations between the Bolsheviks and the National Struggle. The Soviet Union naturally contacted representatives of the National Struggle in Anatolia to achieve this goal. This relationship was also important for Soviet Russia because the establishment of the new regime in Anatolia would be a victory of the Soviets against the West. The Bolsheviks began to deal with representatives of the National Struggle from the first days of the independence war and paid attention to contact them. The first direct meeting of the Soviets on this issue was held in Havza. Husamettin Erturk stated that such a meeting took place in Havza, and that during this meeting, General Budienni "wanted to fight against the Entente states in Anatolia and promise military and money aids for Turkish National Struggle". During the meeting with the Bolsheviks, Russia constantly asked the representatives of the National Struggle to be communists, and in return said that it would provide weapons, ammunition, money, and military aid. Russia was constantly using the weapons, soldiers and ammunition aid needed in the National Struggle, as a trump card against Ankara. In contrast, representatives of the 
National Struggle never thought of being a communist, In contrast, representatives of the National Struggle never thought of being a communist, they seemed to intention to communism just to get these benefits from Russia. When the Bolsheviks' wishes are analyzed, they also saw the National Struggle as an opportunity to implement their regimes and they try to control Anatolia by taking advantage of the conditions of the period. The situation of the National Struggle team at that time compelled them to cooperate with the Bolsheviks. But even though Mustafa Kemal and his friends had warm contacts with Russia and received help, they never entered into an ideological rapprochement. And this cooperation remained a temporary geopolitical alliance, and Bolshevism was not allowed to strengthen in Anatolia. It is possible to understand more clearly the limits and aims of the relations of the National struggle with Soviet Russia for that period from the letter of Mustafa Kemal, which he wrote to Lenin. Pasha had explained that the imperialist and capitalist world attacked with concern that their peoples would follow this way because the Turkish and Russian peoples threw the yoke chains that had been going on for centuries, stated that it created a spontaneous closeness between the two peoples. The letter also mentioned the differences between the struggle of the two peoples, Regime change was not the result of a revolution in Turkey such as Russia, National Struggle was the result of foreign invasion Mustafa Kemal also wrote that "the capitalist" and "bourgeois" understandings in Turkish society was different from Russia, that the "solidarity between classes" in Anatolia was a historical tradition. And so the continuation of this cooperation was limited to common goals in foreign policy and a conjunctive stance according to new Turkish leadership. While an ideological rapprochement with the Bolsheviks was rejected, the National struggle had military successes that would compel the Greek and British armies to peace, and almost dominated the borders set by the Mudros Armistice in 1918. The truth was that the aid of Soviet Russia was very important in these military achievements. The National Struggle As of 1920, Ankara had formed its parliament and became a government in parallel with Istanbul. Soviet Russia had helped the National Struggle to gain legitimacy from the diplomatic point of view by keep relationships with the Ankara government. Having reached almost victory with the peace of Mudanya on 11 October, the team of Mustafa Kemal managed to legally end the Ottoman reign that ruled from 1299 on 1 November 1922. With the Sultan leaving the country 10 days later, the legal obstacles in front of the new state were almost removed, A new nation-state was established on Ottoman lands. If we summarize the situation again to understand the Bolshevik impact of the Republic. After the First World War, the Ottomans lost, their lands were occupied, their parliament was closed, but still officially existed. The Sultan's departure from Istanbul and the abolition of the sultanate were implemented not by the victorious states, but by the National Struggle. The team in Ankara had to clash with the Istanbul government after a stage of the National struggle, and at the end of this struggle, the victory of Ankara was not only over the Greeks but also over the Sultan government, which was supported by the British. In the competition between the administrations in Ankara and Istanbul, both the diplomatic, money, and arms aid of Moscow to Mustafa Kemal and his friends were very important details. The support and effects of the Bolshevik revolution on war and diplomacy were mentioned, but after the establishment of the Republic, it is possible to see similarities with Soviet Russia in some actions. In the period after the establishment of the republic, it is possible to write the administration of one party to the similarities shown with Soviet Russia. That is the Soviet Union's Communist Party as the only party, Turkey had a similar situation. Namely, the People's Party was the only party in 1923-1945 in Turkey, and also it was a government party such as the Communist Party of Russia. Another similarity was the abolition of noble titles, So removed the noble titles in Soviet Russia by 1917. All titles of nobility and in subsequent years with the surname law was abolished in Turkey."Milliyet" newspaper reported this decision as the abolition of titles reporting class inequality. Although the establishment of the Republic of Turkey was not a result of a revolution and the class struggle,this decision could be characterized as the impact of Soviet influence. Another example is Mustafa Kemal's alphabet reform, which he guided. Namely, the Arabic alphabet used by the Turkish and Muslim communities in the Ottoman Empire and before was changed. In 1928, the Turkish alphabet was created on the Latin alphabet and the old alphabet was banned in the country. In this reform, it is difficult to find an exact similarity with Russia, because the Russians continued to use the same alphabet for that period. But a very significant detail In Azerbaijan, which turned into the Soviet Republic by 1920, the Arabic alphabet was removed as of 
1922 and replaced by the Latin alphabet. Especially during the years of the National War, a significant portion of the Bolsheviks' aids had come through Azerbaijani Bolsheviks. And the situation can be understood more clearly when viewed from this perspective.

\section{CONCLUSION}

As it can be seen that the main subjects of the subject we are working on were generally based on two countries. One of them was impressive and the other was affected one. And those two empires that were the source of our research, the Ottoman and Russia were ruled with a monarchic structure for centuries, and especially since the 17th century, they were in harsh competition with each other. Looking at the general course of relations, a war broke out almost every quarter of the century between these two powers. By the end of the 19th century, after the battle of 1877-78, both states seemed to prefer to deal with diplomatic means rather than active wars until World War. Another important point was that there was no permanent hostility between the Turkish and Russian societies after such a long war, we can understand this from the relations that emerged as soon as the First World War ended. By the 20th century, the balances in the world are changing, and the progress in the world in industry and science, especially in Europe, was opening the doors of another period. While there were breakthroughs in industry and science, the moral understanding of the French revolution in the political sense was generally accepted in Europe, and political and economic freedoms increased significantly in Western Europe. And, as mentioned above, the Ottomans and Russia couldn't catch the spirit of this new era. And the time of World war these two empires faced collapse, but there were differences in the collapse process and its results. The Monarchy in Russia was destroyed by internal revolution, but later a more cosmopolitan structure was established based on the Bolshevik ideology. On the other hand, a more cosmopolitan religious empire was overthrown by a nationalist group, that had organized against foreign invaders, and a more nation-based republic was established, in the next stage at the end of World War I, Soviet Russia begin to penetrate beyond the limits of old Russian Empire, but Turkey, did not even attempt to spread to areas in the old borders of the Ottoman Empire, it was closed on itself. In this case, the expansionist side tried to spread its influence in Anatolia, trying to convert the National Struggle to a Bolshevik structure. But it was not a single target of Russia in that period; they also prevented the British and their allies from strengthening in Anatolia after Mudros Armistice. Considering the historical process, the Bolsheviks were unable to establish the Soviet republic in Turkey, but it is possible to see their effects on the reforms of the New Turkey Republic for that period. Finally, if we summarize the process in general, until the Revolution 1917, the Russians and the Ottomans had effects on each other, even with the means of competition and war by historical context. On the other hand, the study showed that the February revolution was a very vital stage on the road to the October revolution, but it was insufficient to explain the subject alone. The October Revolution was the part of the Russian Revolution that had certain effects on the Ottoman Empire. Although Brest Litovsk peace was one of the most prominent elements of this effect, even after the First World War ended, this effect continued on the Turkish National Struggle. It should be added that the National Struggle had a role in the collapse of the Ottoman Empire after the First World War. If we consider the Bolshevik support in the strengthening of the Turkish National struggle, the place of the Russian revolution gains special importance in the last fate of the Ottomans. After the period of establishment of the new republic, it is possible to observe the influence of the Soviet system and ideologies on the reforms of Mustafa Kemal. As a result, The Russian revolution was not successful in building the Soviet republic in Anatolia, but it was possible to see its structural and ideological traces in the new order.

\section{REFERENCES}

[1] Leo Trotski, The History of The Russian Revolution, 2000 by Chris Russell for Marxists Internet Archive

[2] Rex A. Wade, the Russian Revolution 1917, (trans Ergin Ozler), İstanbul 2018

[3] Husamettin Erturk, "Behind Scene of Two Period", İstanbul 1996

[4] Seventeen Moments in Soviet History - Vladimir Lenin, April Theses, Pravda, 20 April 1917

[5] İlber Ortayl1, "XVIII. Century Turkish-Russian Relations", Ankara 1999

[6] Publish of decree about alphabet reform in official newspaper- (https://www.resmigazete.gov.tr /arsiv/ 1030)

[7] Harry J. Psomiades, The Eastern Question, the Last Phase: a study in Greek-Turkish diplomacy (Pella, New York 2000) 
[8] Recep Kochigit, "The reactions of The Russian Revolution in Ottoman Parliament" Ankara 2006

[9] Additional Bibliography

[10] The Cambridge History of Russia: Volume 3, The Twentieth Century ,(2006)

[11] Shevket Sureyya Aidemir, The Single Man 2,1964

\section{AUTHOR'S BIOGRAPHY}

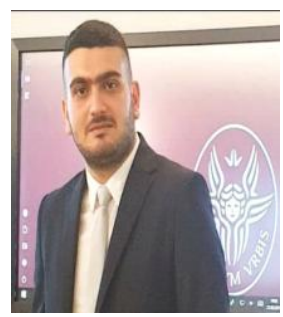

Sabir Mirzazada, He was born in Azerbaijan 1995, Currently, he is a master's degree student of Political Sciences department at Sapienza University of Rome in Italy, According to the bilateral agreement between universities, continues his academic path in International Relations course of the Peoples Friendship University of Russia for the semester.

Citation: Sabir Mirzazada. "The Russian Revolution, Effects on the Establishment of the Turkey Republic" International Journal of History and Cultural Studies (IJHCS). vol 6, no. 2, 2020, pp. 14-20. doi: DOI: http://dx.doi.org/ 10.20431/2454-7654.0602002

Copyright: (C) 2020 Authors. This is an open-access article distributed under the terms of the Creative Commons Attribution License, which permits unrestricted use, distribution, and reproduction in any medium, provided the original author and source are credited. 